\title{
Training in basic Internet skills for special target groups in non-formal educational settings - conclusions from three pilot projects
}

\author{
Andrea Berger and Jutta Croll* \\ Stiftung Digitale Chancen, Berlin, Germany \\ (Received 7 May 2012; final version received 28 September 2012)
}

\begin{abstract}
With the progress of Digital Inclusion, it becomes important to address marginalised groups that face specific barriers in being part of the information society. From 2009 to 2011 within the framework of the nation-wide Initiative Internet erfahren, funded by the German Federal Ministry of Economics, Stiftung Digitale Chancen has accompanied three pilot projects and researched the hindrances and motivations of specific target groups including young migrants from Russia, women in the low-wage sector and disabled elderly people, regarding their use of information and communication technology and related skills. This article describes the teaching methodologies in the training provided in nonformal education settings, exposes the different evaluation methods and sums up the results. A special focus in the discussion is given to the role of the teacher and the relationship between teacher and students as there turned out to be similarities in all three target groups. Understanding the balance between the training and abilities and preferences of the learners will facilitate the further development of training appropriate to those who are still digitally excluded.
\end{abstract}

Keywords: specific target groups in Digital Inclusion; migrants; disabled persons; low-wage sector; barriers towards formal education and technology; student motivation; trainer student relationship

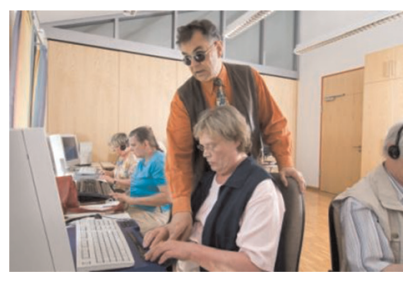

Figure 1. Saulgrub project.

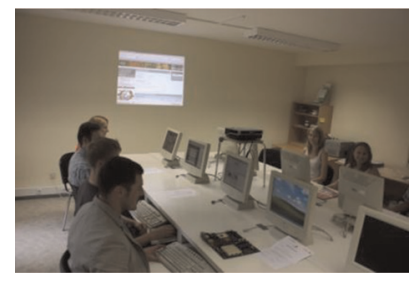

Figure 2. Phoenix project.

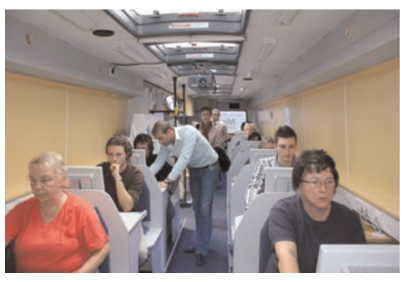

Figure 3. Bremen project. ${ }^{1}$

\section{Introduction}

Since the first representative survey in 2001, the number of people having access to the Internet in Germany has continuously grown from $37 \%$ to $74.7 \%$ in $2011 .^{2}$ This process of Digital Inclusion is accompanied and supported by a variety of measures

\footnotetext{
*Corresponding author. Email: jcroll@digitale-chancen.de
}

RLT 2012. (C) 2012 A. Berger and J. Croll. Research in Learning Technology is the journal of the Association for Learning Technology (ALT), a UK-based professional and scholarly society and membership organisation. ALT is registered charity number 1063519. http://www.alt.ac.uk/. This is an Open Access article distributed under the terms of the Creative Commons "Attribution 3.0 Unported (CC BY 3.0)" license (http://creativecommons.org/licenses/by/3.0/) permitting use, reuse, distribution and transmission, and reproduction in any medium, provided the original work is properly cited. 


\section{A. Berger and J. Croll}

particularly addressing those societal groups that face both barriers in access to the Internet and in requiring digital literacy. In the last 10 years, the focus of Digital Inclusion measures and programmes has shifted. Providing access to the Internet was most relevant in the beginning, now the provision of training for digital literacy is of the highest relevance. We assume that the acquisition of digital literacy skills is affected negatively by two kinds of barriers - barriers that hamper the access of people to education in general, and more specifically those barriers regarding the use of technology in education.

From 2009 to 2011, Stiftung Digitale Chancen (SDC) accompanied and evaluated three pilot projects with different Digital Inclusion approaches specifically addressing women in the low-wage sector, young migrants from Russia and visually impaired elderly people in non-formal education settings. ${ }^{3}$ With methodologies adapted to the different projects, SDC evaluated the training to find out which aspects of the training motivate and encourage the learning process with regard to the targets groups needs, and which aspects possibly hinder the motivation of the participants. In addition, it was the purpose of the evaluation to find out how the concepts could be transferred to different areas and other target groups.

This article aims to contribute towards the accumulation of knowledge about the effects of a precise adaptation of training towards the target group's needs. In addition, attention is paid to the role of the trainer and potential similarities in the demographic background of trainer and students. The results of the evaluation of the pilot projects suggest that similarities in the background of the trainers could be a supportive component to the learning process in non-formal educational settings. ${ }^{4}$

The article first gives an introduction to the current situation of Digital Inclusion in Germany. In the second section, the approach, the evaluation and first results of the three pilot projects are presented. In the third section, the evaluation results are analysed with regard to the common patterns found, and conclusions are then outlined.

\section{Digital Inclusion of special target groups}

In spring 2011, 74.7\% of the German population aged 14 years and older were Internet users or so-called on-liners ${ }^{5}$ - that is, they had used the Internet at least once during the last 12 months according to the (N)ONLINER Atlas, an annual survey focussing on Digital Inclusion. Although there had been a continuous growth in the number of Internet users in the past few years, in several target groups the number of users was disproportionate to their share of the overall population.

The (N)ONLINER Atlas surveys the Internet-user population with regard to demographic attributes like age, gender, level of education and income annually. The survey also states regional differences in the German states ("Länder") according to various demographic differences. Comprising a sample of around 30,000 people, it is representative of the German population. Nonetheless, the survey does not provide statistics about specific target groups in detail. Although in some years in depth research was undertaken regarding the status of employment of the interviewed persons, it was not possible to gain a full overview of smaller groups of employees in different economic sectors. Also, as the survey was based on computer-assisted telephone interviews, it only includes German-speaking people and therefore does not provide statistics on migrants with no or low-level German language skills. The same reason accounts for the absence of statistics on Internet usage of people with 
disabilities, as some groups like those with impaired hearing are not able to conduct a telephone interview.

Overall, the survey shows that women $(68.9 \%)$ are still lagging behind men $(80.7 \%)$, people with low-level education $(51.4 \%)$ lag behind those who were better educated $(90.8 \%)$, low-income groups $(53.0 \%)$ lag behind those with high incomes $(92.3 \%)$, and Internet usage decreases rapidly with increasing age from $97.6 \%$ in the age group $14-19$ years to only $24.6 \%$ among people aged 70 years and over. In view of the $25.3 \%$ of the German population who do not use the Internet, one can assume that there are special target groups among them that have not up to now been properly reached by the programmes for Digital Inclusion. The identification of such groups and their needs for Digital Inclusion must build on a well-established knowledge of societal groups in general and practical experiences in teaching digital literacy.

\section{Offers precisely adapted to special target groups}

In the framework of the Initiative Internet Erfahren, SDC developed and evaluated training courses for digital literacy offered to three different special target groups. The decision to focus on those groups was based on 10 years of experience of Digital Inclusion programmes on the one hand, and the expertise of partner organisations dealing with specific societal groups, on the other. For example, SDC carried out (with associated partners) five workshops ${ }^{6}$ with the aim to identify the groups still digitally excluded and therefore to be addressed by special measures in 2007. The workshops' results revealed that groups facing several disadvantages, in particular with regard to social as well as Digital Inclusion, could be seen as target groups in need of support. ${ }^{7}$ Thus visually impaired elderly people, young migrants from Russia and women employed in the low-wage sector were chosen for the pilot projects and accordingly, three specific approaches and training curricula were developed.

The following table gives an overview of the characteristics of the three pilot projects (Table 1).

The evaluation of the projects aimed at identifying motivational aspects of the projects and hindrances pertaining to motivation and success. The evaluation considered a research strategy (concept), research dimensions, research instruments and the given samples. Table 2 gives an overview of the three evaluational procedures.

\section{Computer and information technology training for visual-impaired seniors Approach}

The German association of the blind and visually impaired in higher education and jobs (DVBS) set up a training course in basic Internet skills for visual-impaired elderly people for the first time in 2008. SDC accompanied and evaluated two following courses in 2009.

One course entailed a week's enclosure training with daily intensive learning sessions in the morning and afternoon in small groups (see Table 1). No formal final examination took place at the end of the course so that it constituted a non-formal educational provision. The course addressed visually impaired elderly people with low levels or no knowledge in Internet usage, and basic, if any, PC skills to start or expand their knowledge and practice. 
Table 1. Overview on the three pilot projects - approach.

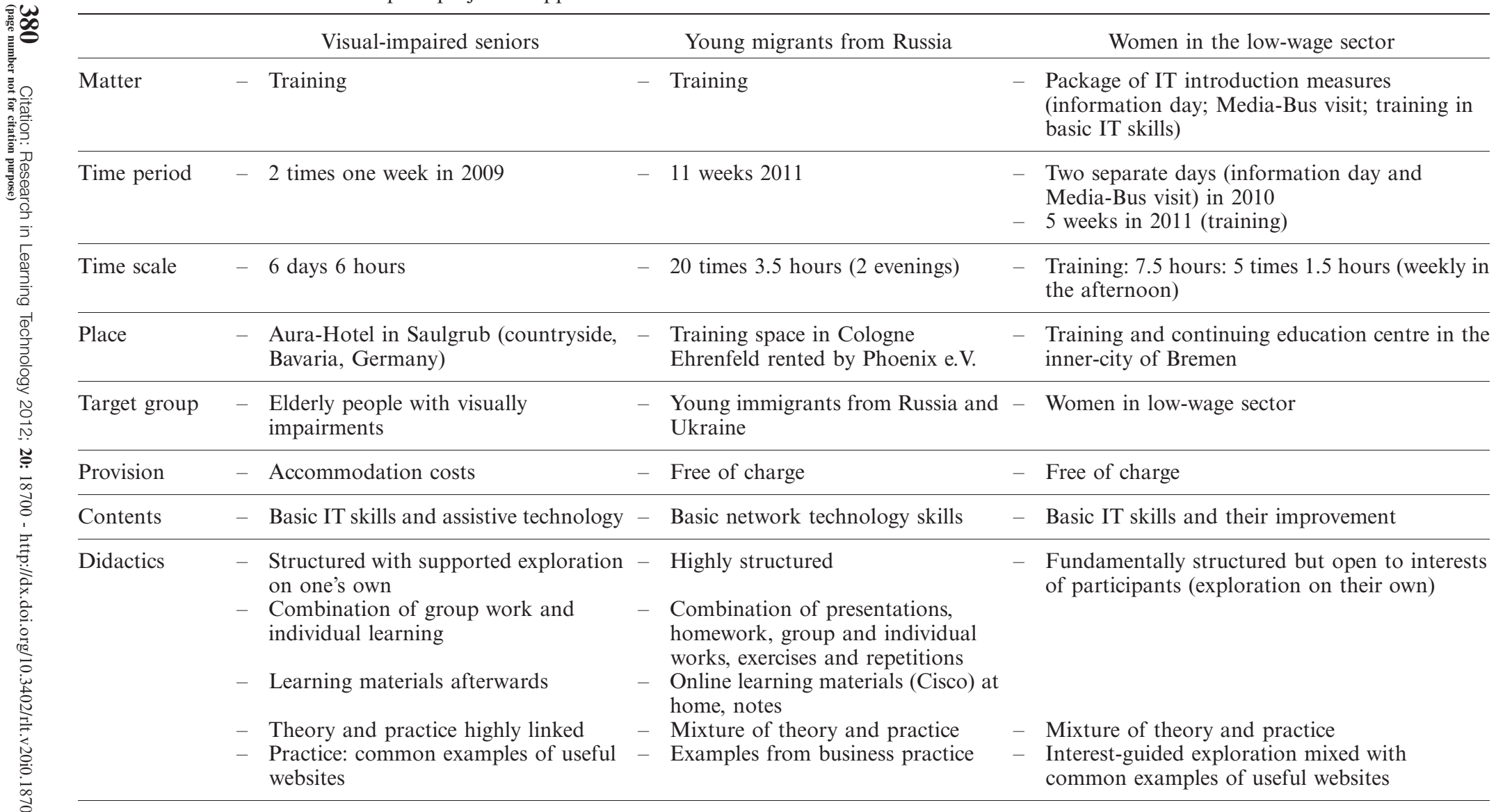


Table 1 (Continued)

\begin{tabular}{|c|c|c|c|}
\hline & Visual-impaired seniors & Young migrants from Russia & Women in the low-wage sector \\
\hline Curriculum & $\begin{array}{l}\text { - PC usage and mail programs (local } \\
\text { clients) and deployment of assistive } \\
\text { technologies ( } 2 \text { days) } \\
\text { - } \text { Basic Internet use and deployment of } \\
\text { assistive technologies ( } 3 \text { days) }\end{array}$ & $\begin{array}{l}\text { Fundamentals: } \\
\quad \text { General information, } \\
\text { hardware (week 1-2) } \\
\text { Software, operating systems, } \\
\text { Windows XP (week 3-4) } \\
\text { Microsoft Office professionals } \\
2003 \text { (week 5) } \\
\\
\text { Core competences: } \\
\text { Network: LAN, TCP/IP, } \\
\text { Ethernet, DHCP, DNS, ping, } \\
\text { ipconfig, tracert (week 6) } \\
\text { Network: hardware, adapter } \\
\text { settings, model OSI-ISO, } \\
\text { protocol TCP/IP (week 7) } \\
\text { Network: WLAN (week 8) } \\
\text { Telephony (week 9) } \\
\text { During performance: security } \\
\text { aspects (week 10) } \\
\text { Exam preparation (week 11) }\end{array}$ & $\begin{array}{l}\text { - Introduction including an overview on the web } \\
\text { and the different forms of web based } \\
\text { communication (week 1) } \\
\text { - How to find sites taking into account the } \\
\text { individual's own interests (week 2) } \\
-\quad \text { Expansion of one's own skills and empowerment } \\
\text { towards using them (week 3) } \\
- \text { Awareness of safety and security aspects in } \\
\text { Internet usage (week 4) } \\
\text { Repeating and deepening of what one has } \\
\text { already learned and is of interest (week 5, } \\
\text { optional) }\end{array}$ \\
\hline $\begin{array}{l}\text { Certificate/ } \\
\text { examination }\end{array}$ & $-\mathrm{No}$ & - Yes, informal & - Yes, informal \\
\hline $\begin{array}{l}\text { Co-operation } \\
\text { partners }\end{array}$ & $\begin{array}{l}\text { - DVBS (German association of the } \\
\text { blind and visually impaired in study } \\
\text { and career) }\end{array}$ & $\begin{array}{l}\text { - Phoenix-Köln e.V. (self-help } \\
\text { organisation from Russian } \\
\text { Migrants in Germany) } \\
\text { - } \text { Cisco Network Academy }\end{array}$ & $\begin{array}{l}\text { - } \text { BLG Logistics } \\
- \text { GHBV (Gesamthafenbetriebsverein in the state } \\
\text { of Bremen) }\end{array}$ \\
\hline Dissemination & - Adverts by DVBS & $\begin{array}{l}\text { - Advert in local Russian newspapers } \\
\text { in Cologne, word-of-mouth } \\
\text { advertising }\end{array}$ & $\begin{array}{l}\text { - Posters from SDC at workplace, Media-Bus visit } \\
\text { and information day at workplace, } \\
\text { information flyers in pay-slips }\end{array}$ \\
\hline
\end{tabular}


Table 2. Overview on the three pilot projects - evaluation design.

\begin{tabular}{|c|c|c|c|}
\hline & Visual-impaired seniors & Young migrants from Russia & Women in the low-wage sector \\
\hline Concept & $\begin{array}{l}\text { Multi-level process to document } \\
\text { learning effects and change in } \\
\text { perception }\end{array}$ & $\begin{array}{l}\text { - Mixture of qualitative and quantitative } \\
\text { evaluation instruments } \\
\text { - } \text { Documentation of progress }\end{array}$ & $\begin{array}{l}\text { - Evaluation with regard to the } \\
\text { different perspectives and expectations } \\
\text { towards the training as well as its effects }\end{array}$ \\
\hline $\begin{array}{l}\text { Research } \\
\text { dimensions/ } \\
\text { key questions }\end{array}$ & $\begin{array}{l}\text { - Effectiveness - achievement of } \\
\text { learning goals? } \\
\text { - Motivation and interests: What do the } \\
\text { participants want to learn? What } \\
\text { should the participants learn? } \\
- \text { Acceptance-course corresponds to } \\
\text { motivation, skills and goals of } \\
\text { participants in their personal view? } \\
-\quad \text { Starting situation - course corresponds } \\
\text { objectively to personal profiles of the } \\
\text { participants? homogeneity or } \\
\text { heterogeneity of the group? } \\
\text { Transferability - possibility to transfer } \\
\text { concept into different constellations/ } \\
\text { regions }\end{array}$ & $\begin{array}{l}\text { - Organisation - main conditions of the } \\
\text { project } \\
\text { - Content - all kind of content provided } \\
- \text { Didactics/methods - methodical aspects } \\
- \text { Motivation and interests of the target } \\
\text { group - motivation to take part of the } \\
\text { learning program and motivation progress } \\
\text { within prolonging of the course } \\
-\quad \text { Sustainability (optional) - performance of } \\
\text { the skills and knowledge afterwards } \\
\text { - Transferability - possibility to transfer } \\
\text { concept into different constellations/ } \\
\text { regions }\end{array}$ & $\begin{array}{l}\text { - Organisation - main conditions of the } \\
\text { project } \\
- \text { Content - all kind of content provided } \\
- \text { Didactics/methods - methodical aspects } \\
- \text { Communication - communication forms } \\
\text { and canals of all participants } \\
\text { - Transferability - possibility to transfer } \\
\text { concept into different constellations/ } \\
\text { regions } \\
-\quad \text { Scalability - scale effects of the concept of } \\
\text { the project }\end{array}$ \\
\hline Instruments & $\begin{array}{l}\text { - Student questionnaire during the } \\
\text { course including personal related } \\
\text { questions (on the spot) } \\
-\quad \text { Student questionnaire after the course } \\
\text { including personal related questions } \\
\text { (telephone interviews) }\end{array}$ & $\begin{array}{l}\text { - Student questionnaire in the beginning } \\
\text { of the course including personal related } \\
\text { questions } \\
\text { - } \text { Student questionnaire during the } \\
\text { performance of the course } \\
- \text { Student questionnaire at the end of the } \\
\text { course } \\
\text { - Group interview manual for the interview } \\
\text { with the students } \\
\text { - Feedback questionnaire for the trainer } \\
\text { during the performance of the course for } \\
\text { every week }\end{array}$ & $\begin{array}{l}\text { - Student questionnaire with personal } \\
\text { related questions at the start } \\
\text { - } \text { Quantitative data about the demographic } \\
\text { composition of the workplace } \\
\text { - Group interview manual for the interview } \\
\text { with the participating representatives of } \\
\text { the cooperation partners } \\
\text { - Feedback questionnaire for the teacher } \\
\text { for every session student online } \\
\text { questionnaire in the end }\end{array}$ \\
\hline
\end{tabular}


Table 2 (Continued)

\begin{tabular}{|c|c|c|c|}
\hline & Visual-impaired seniors & Young migrants from Russia & Women in the low-wage sector \\
\hline Sample & $\begin{array}{l}\text { - } 13 \text { participants (course A: } 7 ; \\
\text { course B: } 6 \text { ) } \\
-\quad \text { Aged between } 54 \text { and } 79 \text { (mostly } \\
\text { between } 60 \text { and } 71 \text { ) } \\
-\quad 7 \text { female and } 6 \text { male participants } \\
-\quad \text { German speaking and nationality } \\
-\quad \text { Wider spectrum of education } \\
\text { qualifications and professional } \\
\text { experiences } \\
-\quad \text { Usage of assistive technology for blind } \\
\text { people } \\
\text { - With one exception all pensioned }\end{array}$ & $\begin{array}{l}\text { - } 10 \text { participants } \\
-\quad \text { Aged between } 18 \text { and } 29 \\
-\quad 5 \text { female and } 5 \text { male participants } \\
-\quad \text { Depending on migration background a } \\
\text { wider spectrum of both German and } \\
\text { Russian language skills } \\
-\quad \text { Partly with education qualifications } \\
-\quad \text { Wider spectrum of occupations (school, } \\
\text { apprenticeship search, job search, job, } \\
\text { parental leave) }\end{array}$ & $\begin{array}{l}\text { - Training: } 12 \text { participants; information } \\
\text { event: } 1 \text { visitor; Media-Bus visit: } 43 \\
\text { visitors } \\
\text { - } \text { Training: aged between } 40 \text { and } 60 \text { with } \\
\text { one exception (younger) } \\
\text { - Training: female participants only } \\
\text { - } \text { Training: German speaking and with one } \\
\text { exception German nationality } \\
\text { - Training: wider spectrum of education } \\
\text { qualifications } \\
\text { - Training: mostly parents } \\
\text { - Training: working in low-waged shift } \\
\text { work }\end{array}$ \\
\hline
\end{tabular}




\section{A. Berger and J. Croll}

To meet the users' needs for comfort and self-determination, the course took place in the "Aura-Hotel" in Saulgrub (Bavaria, Germany), a cure and rehabilitation centre and sanatorium for guests with special needs entailing visual impairments run by the Bavarian Association of the Blind and Visual Impaired (BBSB).

A blind teacher, educated in pedagogy for blind people and experienced in information and telecommunication systems, was appointed to the task of being trainer.

\section{Evaluation}

The evaluation was driven by a motivation to gain findings on the effectiveness of the course regarding the acquirement of basics in Internet literacy. If learning effects could be recognised, further questions would raise up regarding aspects that had been helpful and supportive and those that had been a hindrance or frustrating.

Two questionnaires were therefore developed for multi-level questioning. The participants answered one questionnaire during the training courses on-site and the other one via telephone 2 months after the course. In both questionnaires, access to PC and Internet and related skills before and after the course were surveyed. The first questionnaire included additional questions on the aims and motivation for taking part in the training and on the satisfaction gained in participating. Questions orientated to the subject's age, gender, income and the time they experienced their first visual impairment were part of both questionnaires. The second questionnaire focussed on the habits of PC and Internet usage after training, and how satisfying the training and the uptake of skills after 2 months had been for the individual.

During the first survey phase, the evaluator immediately got into personal contact with the participants and trainer in order to motivate the participants to become subjects in the survey. While taking part for 1 or 2 days of each of the training courses, the evaluator formed an impression of the structure and practices of the training as well as of the atmosphere during the sessions. The evaluator's personal presence at the survey allowed to carrying out the interviews without any technical means. The second part of the questioning was conducted via telephone interview with the participants at their homes.

The data collected in the questionnaires were processed and aggregated in the first place to describe motivation, previous knowledge and personal satisfaction with the training (for an example see Table 3). Due to the small sample size, a statistical analysis of the data was not worth undertaking.

The given data were counted, but also carefully interpreted and validated by the additional information received from open-ended questions (see Table 4).

The analysis focussed on a careful interpretation of correlations between previous knowledge, satisfaction and usage after the course concerning motivational or hindering aspects in the training.

\section{Results}

The approach to make visually impaired elderly people acquainted with digital media is quite structured as regards time and methods (see Table 1). The training concept lowers possible thresholds to participation with the provision of adequate technical equipment at place, accessibility of accommodation and the option to take part without previous knowledge, but a high learning intensity and the duration, distance from home and costs for travel and accommodation might also set obstacles. 
Table 3. Part of analysis table - closed question.

\begin{tabular}{|c|c|c|c|c|c|c|}
\hline Question & Codes & Selections & g. A & g. B & Total & $\begin{array}{c}\text { No } \\
\text { answer }\end{array}$ \\
\hline & No PC access & & $\begin{array}{l}---- \\
-+-\end{array}$ & $\begin{array}{l}--+ \\
---\end{array}$ & $2: 13$ & 0 \\
\hline & Access to PC & & $\begin{array}{l}++++ \\
-+\end{array}$ & $\begin{array}{l}++-+ \\
++\end{array}$ & $11: 13$ & 0 \\
\hline
\end{tabular}

\begin{tabular}{|c|c|c|c|c|c|}
\hline Autonomy & & & & & \\
\hline \multirow{3}{*}{$\begin{array}{l}\text { ("Do you use PC } \\
\text { mostly on your own, } \\
\text { together with other } \\
\text { people or in both } \\
\text { ways?") }\end{array}$} & Autonomously & $\begin{array}{l}++++ \\
+-+\end{array}$ & $\begin{array}{l}+--+ \\
-+\end{array}$ & $9: 11$ & 0 \\
\hline & $\begin{array}{l}\text { Together with } \\
\text { other people }\end{array}$ & $\begin{array}{l}---- \\
---\end{array}$ & $\begin{array}{l}--- \\
---\end{array}$ & $0: 11$ & 0 \\
\hline & In both ways & $\begin{array}{l}---- \\
---\end{array}$ & $\begin{array}{l}-+- \\
-+-\end{array}$ & $2: 11$ & 0 \\
\hline \multicolumn{6}{|l|}{$\begin{array}{l}\text { - Closed question } \\
\text { (one selection) }\end{array}$} \\
\hline $\begin{array}{l}\text { - Nominal scale } \\
\text { - Behaviour-related } \\
\text { question }\end{array}$ & & & & & \\
\hline
\end{tabular}

All participants in the two training courses expressed their motivation to learn or expand their digital literacy. Many participants especially mentioned learning how to send and receive emails as the main objective for taking part in the training. Obstacles to writing in longhand and reading caused by the sight impairment of the participants make the special value of emailing for this target group quite logical. Some of the participants also wanted to improve their PC usage for writing and archiving files and documents. Apart from one person who left the course after 1 day, all other participants fully took part in the course until it ended. Even those made huge efforts to finish it, that felt that the training was quite intense.

There was no valid proof for a direct correlation between previous knowledge and the later habits of usage. However, it seems that for people who had a broad knowledge previously, the learning experience had been easier. Participants with little or no previous knowledge complained more often about the intensity of the course, but also often achieved a wider spectrum of usage than before still 2 months after the course (see Table 5).

In total, the participants were satisfied with the conditions of the course. Comments about the trainer's patience, his willingness to interact and answer questions, and his specific knowledge, due to his own handicap, were often mentioned. Participants with high satisfaction in the training obviously agreed more often that they would take a similar course again. Participants critical of the course benefited less, and they did not integrate the proficiencies into their daily or weekly routines as much as the satisfied ones did 2 months after the course (see Table 5). 


\section{A. Berger and J. Croll}

Table 4. Part of an analysis table - open question.

\begin{tabular}{|c|c|c|c|c|c|}
\hline Question & Codes & Citations & g. A & g. B & Total \\
\hline $\begin{array}{l}\text { Motivation } \\
\text { "Which aspects of } \\
\text { the course } \\
\text { proposal did you } \\
\text { especially } \\
\text { appreciated?" } \\
\text { - open question } \\
\text { - (eventually } \\
\text { opinion } \\
\text { question) }\end{array}$ & $\begin{array}{l}\text { Disability- } \\
\text { related }\end{array}$ & $\begin{array}{l}\text { A: } 7 \text { Blind-specific PCs } \\
\text { available. } \\
\text { B: } 1 .(\ldots) \text { Dependence for } \\
\text { courses especially adjusted to } \\
\text { needs of visually impaired } \\
\text { people. }(. . .) \\
\text { 2. Teacher himself is blind, he } \\
\text { is well informed and can } \\
\text { answer to all questions: It is } \\
\text { different from a seeing person } \\
\text { to teach from the practical } \\
\text { experience if a blind person can } \\
\text { teach from blind practical } \\
\text { experience. }\end{array}$ & + & ++ & $3: 13$ \\
\hline & $\begin{array}{l}\text { Age- } \\
\text { related }\end{array}$ & $\begin{array}{l}\text { A: } 5 \text {. One age group } \\
\text { secures and equalises the } \\
\text { learning speed. } 6 \text {. That the } \\
\text { course is offered especially to } \\
\text { seniors. (...) } \\
\text { 7. That the course is for elderly } \\
\text { people (to be amongst } \\
\text { ourselves): One can withdraw } \\
\text { from the arrogant pressure to } \\
\text { perform by the youth (K: said } \\
\text { with humour), this is my } \\
\text { experience from youth (by my } \\
\text { own children): "Mom, i'll do } \\
\text { that for you!"; It's good to } \\
\text { know, that no one is looking } \\
\text { down on another; (...) }\end{array}$ & +++ & & $3: 13$ \\
\hline
\end{tabular}

Translated from German to English, A. B.

Furthermore, due to the equipment provided, and the accessible facilities, the participants were able to organise their daily routine for the most part autonomously, and the chosen location was therefore highly welcomed by all participants.

Asked if they would prefer a training course close to their homes, that would be offered twice or three times a week, many participants answered that such an offer could not be realised in rural areas because of the small number of visualimpaired people that would be interested in taking part. So far an enclosed training course seems to be the only realistic option for visual-impaired elderly people living in rural areas. Furthermore, some participants liked the age homogeneity of the group arguing this would release them from pressure to keep up with youngsters.

Two out of three participants without a PC at home still did not get the equipment 2 months after the course, so they could not start to practice their skills (see Table 5). An investment in PC and Internet equipment before the start of the training can therefore be recommended. 
Table 5. Conformity of expectations with regard to previous experiences, progress and course rating.

\begin{tabular}{|c|c|c|c|c|c|c|c|c|c|}
\hline \multirow[b]{2}{*}{ S. } & \multicolumn{2}{|c|}{ Previous knowledge } & \multicolumn{2}{|c|}{$\begin{array}{l}\text { IT usage during } 2 \text { months after the } \\
\text { course (judged by participants) }\end{array}$} & \multirow{2}{*}{$\begin{array}{l}\text { Conformity of } \\
\text { expectations: } \\
\text { progress }\end{array}$} & \multicolumn{3}{|c|}{ Rating by participants } & \multirow[b]{2}{*}{$\begin{array}{l}\text { Conformity of } \\
\text { expectations: } \\
\text { previous rating }\end{array}$} \\
\hline & $\begin{array}{l}\mathrm{PC} \\
\text { programs }^{8}\end{array}$ & Mailing $^{9}$ & Frequency $^{10}$ & Range $^{11}$ & & Progress $^{12}$ & Intensity $^{13}$ & $\begin{array}{l}\text { Concept } \\
\text { ("take again") })^{14}\end{array}$ & \\
\hline A1 & Sound & Yes & Daily & Wide & Yes + & Fine & Fine & Yes & Yes + \\
\hline A 2 & Little if any & Yes & 2-3 times a week & Small & Yes - & Fine & Fine & Yes & $\mathrm{No}+$ \\
\hline A3 & Sound & No & Daily & Wide & $\mathrm{No}+$ & Fine & Not so well & Yes & Yes - \\
\hline A4 & Sound & Yes & Daily & Wide & Yes + & Fine & Fine & Yes & Yes + \\
\hline A5 & Little if any & Yes & Daily & Wide & $\mathrm{No}+$ & Fine & Fine & Yes & $\mathrm{No}+$ \\
\hline A6 & Sound & No & Without IT access & $\begin{array}{l}\text { Without IT } \\
\text { access }\end{array}$ & Yes - & Fine & Fine & Yes & $\mathrm{No}+$ \\
\hline A7 & Sound & Yes & Daily & Wide & Yes + & Fine & Fine & Yes & Yes + \\
\hline $\mathrm{B} 1$ & Little if any & No & Without IT access & $\begin{array}{l}\text { Without IT } \\
\text { access }\end{array}$ & Yes - & Not so well & Not so well & Other & Yes - \\
\hline B2 & Sound & Yes & 1 time a month & Small & $\mathrm{No}-$ & Fine & Not so well & If $\ldots$, and other & No - \\
\hline B3 & Little if any & No & 2-3 times a week & Small & Yes - & Not so well & Not so well & If... , and other & Yes - \\
\hline B4 & Sound & Yes & Daily & Wide & Yes + & Fine & Not so well & Other & $\mathrm{No}-$ \\
\hline B5 & Sound & No & 2-3 times a week & Small & Yes - & Fine & Fine & Yes & $\mathrm{No}+$ \\
\hline B6 & Little if any & No & Daily & Small & $\mathrm{No}+$ & Fine & Not so well & Yes, and if ... & Yes - \\
\hline & \multicolumn{5}{|c|}{ Note: } & \multicolumn{4}{|c|}{ Note: } \\
\hline & \multicolumn{5}{|c|}{$\begin{array}{l}\text { yes }+ \text { : participants with profound previous knowledge in } \mathrm{PC} \text { and/or mailing use } \\
\text { IT often and within wider spectrum of applications (expectation) }\end{array}$} & \multicolumn{4}{|c|}{ yes + : participants with profound previous knowledge in PC and/ } \\
\hline & \multirow{2}{*}{\multicolumn{5}{|c|}{$\begin{array}{l}\text { no +: participants with little if any previous knowledge in PC and/or mailing use } \\
\text { IT frequently and/or within a wide spectrum of applications (against expectation) }\end{array}$}} & no + : partici & ants with little & any previous knov & ledge in PC and/ \\
\hline & \multirow{2}{*}{\multicolumn{5}{|c|}{$\begin{array}{l}\text { yes -: participants with little if any knowledge in PC and/or Mailing will use the } \\
\text { Internet less frequently and within a little spectrum of applications (expectation) }\end{array}$}} & \\
\hline & & & & & & \multicolumn{4}{|c|}{ yes -: participants with little if any knowledge in PC and/or } \\
\hline & & Mailing are & ss satisfied wi & the course (expect & tion) \\
\hline & \multicolumn{5}{|c|}{$\begin{array}{l}\text { Internet less often and/or within a small spectrum of applications (against } \\
\text { expectation) }\end{array}$} & \multicolumn{4}{|c|}{$\begin{array}{l}\text { no - : participants with sound previous knowledge in PC and/or } \\
\text { mailing are less satisfied with the course (against expectation) }\end{array}$} \\
\hline
\end{tabular}




\section{A. Berger and J. Croll}

\section{Network technology training for young migrants from Russia}

\section{Approach}

Young students with migrant backgrounds are still part of the disadvantaged population in terms of education in Germany. ${ }^{15}$ To take further efforts and approach their needs and preferences, SDC set up a training course in basic network technology skills held in the Russian language for young people from Russia living in Germany. In co-operation with the Cisco Network Academy and Phoenix e. V., a self-help organisation of Russian migrants in Cologne, a training schedule was developed and organised in 2010 (see Table 1).

The training made use of different language versions in the Cisco learning platform to open up Network training to young people speaking the Russian language as their mother tongue. The trainer himself was a migrant from Russia. He had been educated first in the Cisco Network Academy and was certified as a teacher for basic Network technology skills in the Cisco program.

\section{Evaluation}

The evaluation aimed at answering the question whether providing training in the mother tongue increases the motivation to learn? With the analysis of the data, it should become possible to flesh out the relevant supporting aspects on the one hand, and identify those that were preventing a positive learning experience to the students, on the other hand.

Student and teacher questionnaires were drawn up to receive the required information. Three questionnaires were given to the students at three different times: one at the beginning, one during and one in the end of the course. Furthermore, the students were invited to a group interview to discuss the concept of the training, to let the evaluators know their perception of the training in situ conditions and discussion, and to find out about values and attitudes towards parts of the training to better understand the findings from the previous surveys (see also Table 1 for evaluation design).

The teacher kept weekly records of his own impressions of the students motivation, their presence and the learning requirements with regard to the different topics.

Due to the small sample size, a statistical analysis of the data was not recommended. The evaluator first processed the given data.

In the analysis a careful interpretation of the countable data was carried out and validated by answers to open questions in the questionnaire and the results of the qualitative analysis of the group interview (see Figure 4) along the research dimensions (see Table 1).

\section{Results}

Due to the curriculum, final examination and teaching methods (see Table 1), one can describe the training approach as highly structured. The threshold to take part was high due to high learning load with regard to little previous knowledge in the area and due to a personal interview before acceptance at the start. However, provision of the training and learning materials in the mother tongue have been judged beforehand as a motivational intensifier. 


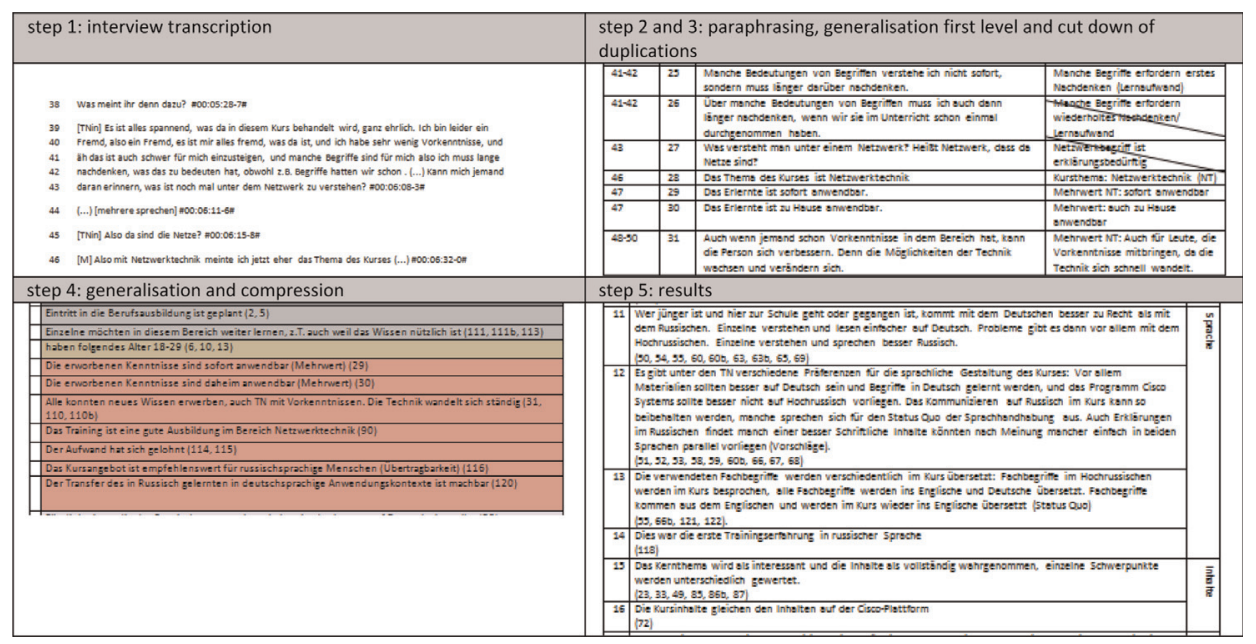

Figure 4. Display of qualitative content analysis of group interview after Mayring. ${ }^{16}$

According to the results of the final examination in which all participants succeeded, and according to their own impression of the training, the participation was hugely successful for all the participants as to the learning effects.

For nearly all the participants their interest in the topic, and the relevance of the knowledge in their professional life, accounted for their motivation to participate in the training (see Table 6).

Only two out of ten participants mentioned the use of the Russian language as a reason to take part in the course.

Because of differences in the migration history of the participants, a few problems with the written Russian language of the Cisco learning platform occurred for some participants who asked for help with translation. Participants with a good knowledge in written and spoken Russian, as a result of their migration history, benefited from the teaching language both in the written and oral form (see Table 6).

It was pointed out in the group interview with the students, as well as in the questioning of them and their teacher, that the spoken Russian language was nonetheless of benefit to the training. Students suggested several options to improve the training course with regard to the use of language, but wanted to stay with Russian language. Students would include two different versions of the written information (programme and so on) that is to have Russian and German in parallel. Like the trainer, they further emphasised that a good group atmosphere helped them to relax during the breaks from learning.

The teacher felt the use of the mother tongue supported the group atmosphere which further helped to compensate the heavy study load. As one can see in Table 7, in the first weeks and especially in week 6 when the core topic "network" 18 started (see Table 1 for topics), the trainer judged the learning load for some students as high.

The results indicate further that the practicing exercises with the hardware, the interest of the students towards the topic and the regular learning exercises to repeat the content of the previous lesson in their own words have been the main factors to compensate for a heavy learning load. 


\section{A. Berger and J. Croll}

Table 6. Results of group analysis with regard to participations motivation and language preferences.

Meanings, abstracted

Content category

Motivations to participate at the training are interest towards the topic, Motivation achievement of relevant skills for one's own professional carrier and extension of one's knowledge in the area. $(3,5 b, 7,9,12,14)$

Younger participants and those that went to school in Germany learn better in German than in Russian language. Some individuals understand German better and reading in German is as well easier for those. Problems occur mostly in these cases with written Russian language. Some participants understand the Russian better than German and for those it is also easier to speak in Russian. $(50,54,55$, $60,60 \mathrm{~b}, 63,63 \mathrm{~b}, 65,69$ )

The participants have different preferences for a future design of a training programme with regard to language: Especially learning materials one should better offer in German, as well as terms. One should better not offer the Cisco learning programme in written Russian language. One can keep oral communication in the training in Russian language. Some participants would keep the status quo of the language use of the training for the future. Few participants actually prefer explanations in Russian language and some participants propose to have two written language versions of the programme, one in Russian and one in German. (51, 52, 53, 58, 59, 60b, 66, 67, 68)

Status quo of handling terms is done in different ways: in the training one talk about the terms in Russian. The training translates the terms into English and German. Nature of terms is English and one is retranslating them into English in the training. (55, 66b, 121, 122)

For all participants the training has been the first one in Russian language since they live in Germany. (118)

Translated from German to English, A. B.

Table 7. Conformity of expectations for learning experience and adequacy of learning level with regard to previous knowledge. ${ }^{17}$

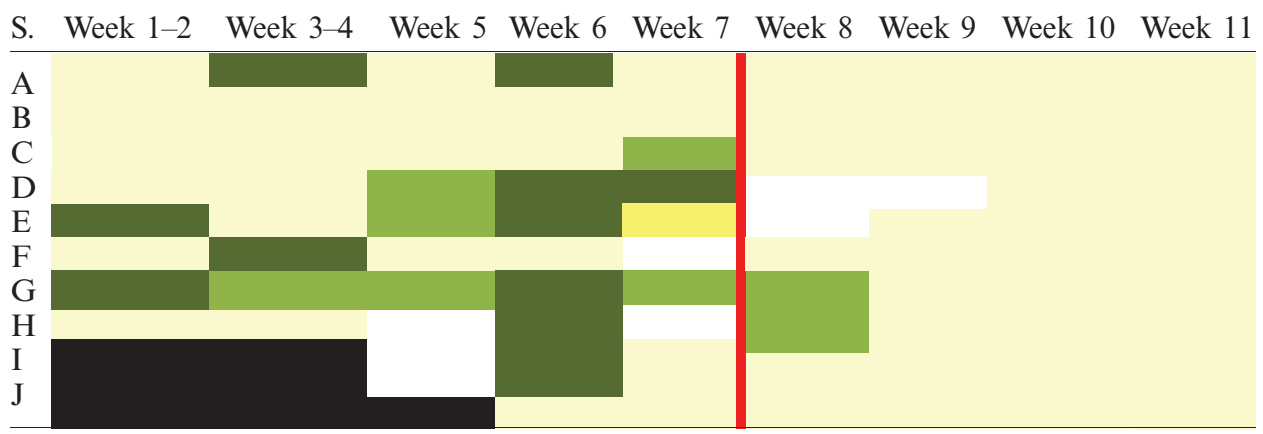

Overstrained, but positive to very positive learning experience

Subchallenged, but positive to very positive learning experience

Positive learning experience as expected - learning level is adequate with regard to previous experience

Negative learning experience as expected - learning level is adequate with regard to previous experience

Absent on two course sessions in week

Later course start 
The topic "network", which the trainer thought to be the most difficult and annoying one, was judged by many students as of high interest. ${ }^{19}$

\section{Internet and Web 2.0 training for female workers in the low-wage sector}

\section{Approach}

Women working in the low-wage sector face double barriers in terms of education in technology: according to current data women are still less likely to make use of information and communication technology than men in Germany. ${ }^{20}$ Second, the digital divide is growing in correspondence with the level of education. Differences between the male and female adult population regarding access to the Internet increases when comparing parts of the population with lower education and/or lower income with those groups with higher education and/or higher income. ${ }^{21}$ When in 2010, D21 the initiative described six user types in digital society, the so-called "digital outsider" was statistically described as being mostly a female, with low formal educational qualifications, low income, around 65 years old, mostly not employed and often living in a two- or one-person household. ${ }^{22}$ The digital outsider, here represented in a simplified way, is classified as having low user-rates, a low spectrum of usage habits and little knowledge about digital communication and technology. ${ }^{23}$

The development of the pilot project was driven by the assumption that women with low formal education and income could be addressed perfectly well with a lowthreshold strategy at their place of employment. In 2010, SDC and the Bremen Central Office for the Realization of Equal Opportunities for Women, as a local support for knowledge input in gender questions, approached several companies in the warehousing industry in the area of Bremen (Germany) that employed female workers in the low-wage sector. A logistic company and their personnel service company agreed to co-operate with the research.

The low-threshold strategy was realised with three consecutive measures: on-site information provision, an on-site Media-Bus ${ }^{24}$ visit and a training course for basic Internet skills (see Table 1).

Due to a heavy working load, the time-pressure of working in shifts, family issues and low income, the project strategically needed a high level of flexibility and adaptation to meet the needs of female workers. Therefore the information meeting and the Media-Bus visit were placed and scheduled to suit the structure and working times of the women employed and to allow them to visit the two offerings during their breaks and after work. The women were also questioned at both activities about their Internet usage and skills in order to appropriately set up the training curriculum. Furthermore, an information meeting was undertaken before the start of the training in order to ascertain the preferred time slots and to find the dates that suited all the participants the most. The personnel service company and the logistic company also agreed on a level of flexibility in the schedule of shifts of the women participating so to avoid interference in their training.

The design of the training curriculum was meant to meet the interests and needs of female workers. As Web 2.0 applications are considered to be user friendly and supportive to establish a new gender neutral relation towards technology, the curriculum allowed for a playful and interest-based approximation towards the Internet (see Table 1). ${ }^{25}$ The training also included the appointment of a female 


\section{A. Berger and J. Croll}

trainer which was intended to create a trustful atmosphere where the participants could feel free to address all kind of issues.

\section{Evaluation}

The evaluation of the training course covered the analysis of quantitative data of the female staff in order to understand how to reach the target group. In addition, the evaluation aimed to analyse the effects of the training on digital literacy and enquire whether a potentially long lasting intention to use the Internet had been achieved. The instruments used to evaluate the subject were created along six dimensions (see Table 1).

Two very simple questionnaires were set up to ask the participants at the beginning and end of the course and one for the teacher in order to document relevant aspects from each session. The one which was handed out at the beginning of the course included questions relating to demographic attributes and Internet and PC experiences in order to draw a profile of the group (see Figure 5).

Another questionnaire, which was filled in online in the last training session, was intended to ascertain the judgement of the participants in relation to the different aspects of the training and to provide them with the possibility to give evidence of their newly obtained knowledge and skills. A questionnaire for the trainer was also developed to be filled in after each session to keep a record of the specific content, methods and materials applied in the session, and how they were accepted by the participants.

Due to the small sample size a statistical analysis of the data would not have delivered valid results. The given data were processed, but also carefully interpreted and validated with the analysis of additional information gained from open-ended questions in the questionnaire.
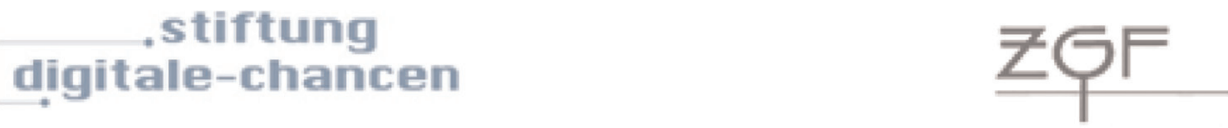

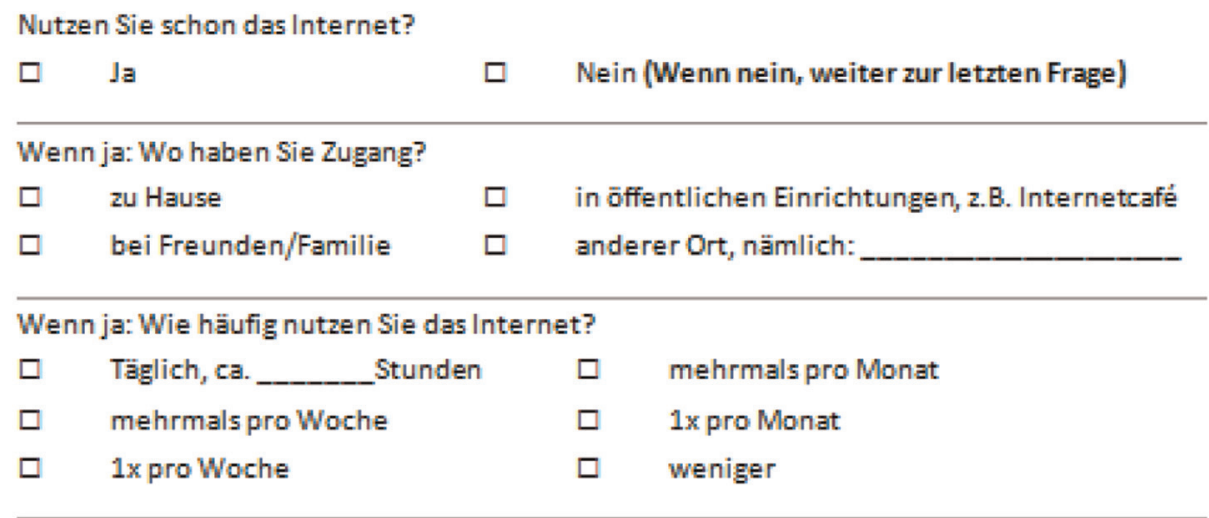

Figure 5. Partial view of participants profile questionnaire. 
To receive information about the attitudes, judgements, perspectives, and aims of the companies involved towards the pilot project, a guided interview was carried out with representatives of the co-operating companies and institutions. Furthermore, data about the female staff working in the logistics company for the personnel service provider was made available by the personnel service provider and could be analysed in the project evaluation. They provided demographic information about potential participants for the offering in order to get a better overview of the target group.

\section{Results}

The key aspects of the Bremen project approach (see Table 1) were, first, more than the other projects presented here, that the project followed a low-threshold strategy, due to flexibility in work shifts, workplace communication and training free of charge. Second, Bremen was, more so than the other projects, directed in a very open way regards content and methods. The interests of the participants constituted the main guidance for content and methods of the training.

The intention to address women at their working place faced big obstacles and needed further intervention. Only one person visited the first information event, though 43 people came to the Media-Bus visit. Only one person had eventually registered for the training course by late 2010. As it was not possible to do the training course during work time the women were offered a financial compensation equivalent to their usual wage. This led to 12 registrations for the course out of possible 256 women. Nine participants filled out the questionnaires and thus represented the sample in the evaluation (see Table 2).

The meagre response to a free offer for Internet training and the information day can be interpreted in several ways: First, beyond routine duties the daily life-load does not leave any room to engage in activities of any other kind other than of a relaxing nature or those tied to leisure. Second, the offer had no relevant value for the women; or third it had not been adequately communicated to them. Fourth, the idea to realise a low-threshold strategy and contact the workers at their workplace did not work out - scepticism towards offers supported by the employer could be a reason. That fact that financial compensation changed the motivation for some of the workers still leaves all the above interpretations feasible apart from the third one as a plausible cause.

A further explanation concerning the female staff arises from analysing the data and the related personal questions of the participants involved in the training. All participants that filled out a questionnaire had some qualifications; two women were actually qualified to go to university. All of them did not, however, as it turned out, take-up a professional education or follow their professional education in their job. Rather than a lack of educational qualifications a discontinuity in their professional careers can be discerned. Thus it can be assumed that only those women who already had a basic level of education were motivated to take part in the training course and to overcome obstacles to participation in their daily life.

After a difficult start in getting the training underway, the training itself was generally judged by the participants as a good and joyful learning experience.

A criticism about the organisation of the course surrounded its scheduled hours, which were judged by the participants as problematic. The women that took part in 


\section{A. Berger and J. Croll}

the training had difficulties partly caused by holidays, shift-reduction, shift-extension or changes in their shift that led to waiting times until the training started, a delay, or finishing the shift earlier than expected. Nonetheless, the participation rate reached a good frequency. The training location in the centre of Bremen was easy to reach and favoured by the women. The trainer added, that due to the fact of ongoing online administration work on the network Internet usage was restricted and that it was not possible to access several Web 2.0 applications.

The participants also contradicted the fourth interpretation made above: they actually welcomed the training offer mediated by their employers. As four participants argued, the idea to participate in trainings like this would not come up. Four participants recommended the strategy by arguing that otherwise they would not have had the time to participate in training like this. This strengthens the first interpretation of the difficulties in starting the course: the daily life-load is so heavy that it does not allow one the opportunity to organise or participate in educational offerings that are not adapted to the work situation or take account of it. The flexibility of the training can be pointed out as an important aspect that motivated the women and allowed their participation.

With regard to the content provided in the different training sessions, the trainer continuously judged the level and suitability of the contents during the progression of the training in relation to the previous knowledge of the participants. Most of the participants judged their comprehension as good - the trainer agreed in the documentation. In relation to Web 2.0 content, the teacher had the impression that the learning group was slightly over-ambitious in trying to master this. Searching options, online shopping, as well as mailing was especially relevant to the participants. With regard to security aspects, information about risks and threats made participants feel they would become more careful in the future and simultaneously made them feel more secure with their improved knowledge.

The participants judged the choice of a female trainer as a very relevant and positive aspect of the training programme and appreciated her teaching methods. The relation between theoretical and practical work was judged, on the whole, as adequate. The mixture between a competent guide and introduction into Internet areas and usage, and exploration by themselves, was useful in holding their interest. Free surfing on the Internet was thoroughly enjoyed. It could also be pointed out that the small group structure with only female participants promoted a positive learning experience.

\section{Synthetic analysis}

The aggregation of the results is leading to the following conclusions with regard to the effects of a training course precisely adapted to the special needs of the target groups.

\section{Motivation and staying power}

The reasons to participate were different in the three target groups and cannot be seen as the only factor that kept up their motivation during their participation in the training courses. For the women in the Bremen pilot project a financial incentive was necessary to increase their motivation to participate in an educational offering that increased their heavy daily life-load and compensate the additional time spent in the 
lessons. Nonetheless, the participants in the training courses followed it for the most part continuously and having enjoyed the learning and practice they left the course highly satisfied.

By contrast, for the elderly visually impaired, financial investment and the journey to the course location was held did not reduce their motivation for taking part in the training. For the young migrants the content of the course was judged as relevant for future job opportunities and therefore contributed to their motivation and strengthened their engagement in the learning process.

Eventually the conclusion can be drawn from the three pilots that motivation and staying power cannot be defined in general. Measures to strengthen motivation need the same specific adaptation to the target group as the learning offer itself.

\section{Satisfaction with the training and own learning results}

The different aspects of digital communication taught in the three different training programmes were highly attractive to the various participants and can be seen as one of the major reasons for following the training courses to the end. The well-adapted training content of the courses enabled the participants to stay interested and motivated even during periods of a heavy learning load.

An important aspect for satisfaction is that each participant can learn something new with regard to the main topic of the course. General experience in PC usage and Internet use at the beginning of the training can be seen as less relevant in terms of satisfaction with the course and the own learning results. In the case of the pilot project with visual-impaired seniors, it could be pointed out that previous experiences, especially in the beginning, facilitated their learning. A heavier learning load for people, with or without little experience, can be managed if the trainer is able to handle the different learning levels and needs of the learners when their interest in the main topic is given.

As the level of skills taught in the three courses was different also the learning results were different, although all trainees could be called successful in the end. Nonetheless it can be concluded that satisfaction with the course and the personal learning results comes along with the appropriateness of the training to the group. It is the benefit of non-formal education that it is not bound to formal requirements and therefore much more free to adapt to special needs. Providing the training in non-formal educational settings has had in all three pilot projects a positive impact on the learning results. Non-formal education is less loaded with expectations on performance in examination and can therefore focus more on imparting knowledge and skills. Future programmes for teaching digital literacy to special target groups should build on that advantage of non-formal education.

\section{Student teacher relation}

Of special significance in all three pilot projects is the fact that a good and trustful relation between trainer and learners has a positive impact towards creating a supportive group and working atmosphere. In Bremen, a female teacher was especially appointed for the group of female learners to prevent them from feeling intimidated and to help create an open learning atmosphere where any question could be raised without embarrassment. In Saulgrub, praise towards the teacher for his pedagogical way of teaching, his commitment and his knowledge, and his 


\section{A. Berger and J. Croll}

practical competence - especially because of his own disability - were frequently mentioned in the interviews. It turned out that being disabled himself gave the teacher's remarks and knowledge about Internet use with assistive technology a different quality in the perception of the learners. In the third pilot project Phoenix e.V., the similar migrant background of the teacher and of the participants ${ }^{26}$ may have justified the use of Russian language even for those participants that had problems with the written Russian language. The spoken Russian language facilitated a good group atmosphere as well as learning atmosphere, even though problems with the written language made it more difficult for students with less written Russian language skills to learn.

All three pilot projects provide very similar findings with regard to the impact of the relation between the trainer and students. Although they are based on practical observations and have a very low level of representativeness, the findings suggest they can be related to a phenomenon described in literature as stereotype threat. According to Aronson \& Inzlicht stereotype threat is "the apprehension people feel when performing in a domain in which their group is stereotyped to lack ability."27 Evidence for the phenomenon was found for women and their technical skills, for various ethnic groups with regard to their intellectual skills, and for seniors and their memory skills. ${ }^{28}$ As stereotype threat is grounded in the student's assumption that the teacher believes in his or her lack of ability, an option to intervene to the threat is to train the student himself to challenge that assumption. Another option in terms of intervening is to choose a teacher or trainer with a similar background and biography to the student since this presupposes that the former will not hold such negative assumptions. ${ }^{29}$ This is discussed in the literature as a successful intervention to stereotype threat and the findings of the three pilot projects support this approach as being successful.

So far stereotype threat has not been considered concerning teaching digital literacy. But from the findings of the pilot projects it has become obvious that attention should be paid to the phenomenon when addressing those special target groups that must still be called digitally excluded and are thus becoming minority groups in society.

Thus from the three pilot projects the conclusion can be drawn that for target groups with special needs regards Digital Inclusion the approach of especially adapted training courses in non-formal educational settings has proven of value.

\section{Notes}

1. (C) Bethel Faht for Initiative "Internet Erfahren" Figure 1 and 3. (C) Stiftung Digitale Chancen for Figure 2.

2. www.nonliner-atlas.de

3. According to UNESCO on the one hand non-formal education settings means "institutionalized, intentional and planned by an education provider." On the other hand, "it is an addition, alternative and/or a complement to formal education within the process of the lifelong learning of individuals", see paragraph 39 in point 4 "Scope of Education in ISCED" in (Unesco 2011), Revision of the International Standard Classification of Education (ISCED), Annex, p. 80/81. The European Commission definition of non-formal learning widely follows the UNESCO definition and furthermore differentiates non-formal education settings from the National Framework of Qualifications, see Office for Official Publications for European Communities (ed.), Classification of Learning Activities - Manual. 2006, p. 20-23.

4. Migrationshintergrund, eds Heinrich-Böll-Stiftung, Münster/New York, p. $125 \mathrm{ff}$ and by Schauenburg, B. 'Stereotype und Erwartungseffekte. Beiträge der Sozialpsychologie 
zur Bildungsdebatte, in Schule mit Migrationshintergrund, eds Heinrich-Böll-Stiftung, Münster/New York, p. 177.

5. According to the (N)ONLINER Atlas a person is called an "onliner" when he/she has used the Internet at least once in the last 12 months.

6. See www.digitale-chancen.de/chancengleichheit.

7. See Niesyto (2010) Medienpädagogik: Milieusensible Förderung von Medienkompetenz, in Medien. Bildung. Soziale Ungleichheit. Differenzen und Ressourcen im Mediengebrauch Jugendlicher, ed Theunert, H. kopaed muenchen, München, p. 150.

8. Based on answers to question, if the participant got any word processing programs or other PC skills or experiences, if so which ones (interview on-site).

9. Based on answers to question, if the participant got any mailing skills or experiences, if so which ones, e.g. file attachment etc (interview on-site).

10. Based on answers to question, how often the participant uses IT on weekly or monthly average in the time period of 2 months after the course (telephone interview 2 months later).

11. Based on answers to questions, what the participant used within IT applications in the time period of 2 months after the course (telephone interview 2 months later).

12. Based on answers to question, how the participant rates the progress of learning in course (interview on-site).

13. Based on answers to question, how the participant rates the learning intensity (interview on-site).

14. Based on answers to the question, "In case the participant would like to do another training course, would he or she take the same course in its form again (telephone interview 2 months later)?"

15. Beicht and Granato (2010) 'Ausbildungsplatzsuche: Geringere Chancen für junge Frauen und Männer mit Migrationshintergrund', BIBB Report 15; 10. Forschungs- und Arbeitsergebnisse aus dem Bundesinstitut für Berufsbildung, vol. 15. See also: Liebig and Widmaier (2009), quoted after Schauenburg (2011), p. 169.

16. see Weischer. (2007). Sozialforschung, UVK Verlagsgesellschaft mbH, Konstanz, p. 362. and Mayring 2000 'Qualitative Content Analysis', Forum: Qualitative Social Research. Sozialforschung, vol. 1, no. 2, Art. 20 - June.

17. Table 7 shows the comparison and correlation of the teachers' weekly documented answers to the questions: "Do you judge the learning level as adequate with regard to previous knowledge of participants?" "How positive or negative do you judge the learning experience, meant by fun or frustration with learning?" for each participant.

18. The topic 'network' refers to technical work with networks architecture for networks at workplace and at home.

19. As Schauenburg points out, an institutional climate of high learning expectations and ambitious learning contents for all students in a learning group support an equal distribution of learning expectations of teachers towards their pupils. See Schauenburg (2011), p. 176. It could be supposed, that as well for pupils ambitious learning contents are supportive and motivating within a positive and encouraging learning atmosphere.

20. See Kompetenzzentrum Technik-Diversity-Chancengleichheit e.V. mit Unterstützung der Initiative D21 und TNS Infratest (2007) (publ.): Internetnutzung von Frauen und Männern in Deutschland 2007. Sonderauswertung Gender \& Diversity des (N)ONLINER Atlas 2007, Bielefeld, September 2007, p. 4 and 11 et seq.). Age also is a cumulative together with gender in Digital Inclusion (see ibid.)

21. Ibid.

22. See Initiative D21 e.V. (2010) (publ.): Digitale Gesellschaft. Die digitale Gesellschaft sechs Nutzertypen im Vergleich. Eine Studie der Initiative D21, durchgeführt von TNS Infratest, p. 10, 12/13.

23. Ibid.

24. The Media-Bus is a motor-coach equipped with $10 \mathrm{PC}$ working stations connected to the Internet.

25. See Zauchner (2011), p. 6 Figure 1: Saulgrub project Figure 2: Phoenix project Figure 3: Bremen project1. 


\section{A. Berger and J. Croll}

26. See Karakaşoğlu (2011) "Lehrer, Lehrerinnen und Lehramtsstudierende mit Migrationshintergrund. Hoffnungsträger der interkulturellen Öffnung von Schule" in Schule mit Migrationshintergrund eds Heinrich-Böll- Stiftung, Münster/New York, pp. 121-135. Karakașoğlu discusses the access to and the special value for formal education sector of teachers with migration background. In the end, she comments that a migration background itself is not enough to be seen as a positive value to open up schools toward diversity, because the competence to reflect the own experiences and integrate them with the professional knowledge need to be supported before, even though empirical hints are given that teachers with migrant background more often show special skills in handling and supporting a good climate of diversity than teachers without migrant background (see ibid., p. 124 et seq.).

27. Aronson and Inzlicht (2004) quoted after Schauenburg (2011) p. 170.

28. Schauenburg (2011).

29. Schauenburg (2011)

\section{References}

Aronson, J. \& Inzlicht, M. (2004) 'The ups and downs of attributional ambiguity: stereotype, vulnerability and the academic self-knowledge of African American college students', Psychological Science, vol. 15, pp. 829-836.

Beicht, U. \& Granato, M. (2010) 'Ausbildungsplatzsuche: Geringere Chancen für junge Frauen und Männer mit Migrationshintergrund', BIBB Report 15/10. Forschungs- und Arbeitsergebnisse aus dem Bundeinstitut für Berufsbildung, vol. 15, pp. 1-16, [online] Available at: http://www.bibb.de/dokumente/pdf/a12_bibbreport_2010_15.pdf [Accessed 19 November 2012].

Initiative D21 e.V. (eds) (2010) Digitale Gesellschaft. Die digitale Gesellschaft - sechs Nutzertypen im Vergleich. Eine Studie der Initiative D21, durchgeführt von TNS Infratest, TNS Infratest.

Karakaşoğlu, Y. (2011) 'Lehrer, Lehrerinnen und Lehramtsstudierende mit Migrationshintergrund. Hoffnungsträger der interkulturellen Öffnung von Schule', in Schule mit Migrationshintergrund, eds Heinrich-Böll-Stiftung, Münster/New York, pp. 121-135.

Kompetenzzentrum Technik-Diversity-Chancengleichheit e.V. mit Unterstützung der Initiative D21 und TNS Infratest, ed. (eds). (2007) 'Internetnutzung von Frauen und Männern in Deutschland 2007. Sonderauswertung 'Gender \& Diversity' des (N)ONLINER Atlas 2007', in Schriftenreihe, no. 5, Bielefeld.

Office for Official Publications for European Communities. (2006) Classification of Learning Activities - Manual, Office for Official Publications for European Communities, Luxembourg.

Liebig, T. \& Widmaier, S. (2009) Children of immigrants in the labour market of EU and OECD countries: an overview, OECD Directorate for Employment, Labour and Social Affairs, Paris.

Mayring, P. (2000) 'Qualitative content analysis', Forum: Qualitative Social Research, Sozialforschung, vol. 1, no. 2, Art. 20 - June, [online] Available at: http://www.qualita tive-research.net/index.php/fqs/article/view/1089/2383 [Accessed 19 November 2012].

Niesyto, H. (2010) 'Medienpädagogik: Milieusensible Förderung von Medienkompetenz', in Medien. Bildung. Soziale Ungleichheit. Differenzen und Ressourcen im Mediengebrauch Jugendlicher, ed. H. Theunert, kopaed muenchen, München, pp. 147-161.

Schauenburg, B. (2011) 'Stereotype und Erwartungseffekte. Beiträge der Sozialpsychologie zur Bildungsdebatte', in Schule mit Migrationshintergrund, eds Heinrich-Böll-Stiftung, Münster/New York, pp. 169-180.

United Nations Educational, Scientific and Cultural Organization (Unesco). (2011) Revision of the International Standard Classification of Education (ISCED), General Conference, 36th Session, Paris.

Weischer, C. (2007) Sozialforschung, UVK Verlagsgesellschaft mbH, Konstanz.

Zauchner, S. (2011) 'Geschlechterforschung. Ihr Blick auf das Lernen und Lehren mit neuen Technologien', in: L3T' Lehrbuch für Lernen und Lehren mit Technologien, eds M. Ebner \& S. Schön, pp. 1-7. [online] Available at: http://13t.tugraz.at/index.php/LehrbuchEbner10/ article/view/72 [Accessed 19 November 2012]. 